\title{
Biologiske faktorer ved suicidal atferd
}

\author{
Ved Lars M ehlum
}

\begin{abstract}
Mange årsaksfaktorer har betydning ved suicidal atferd - både biologiske, psykologiske og sosiale forhold - og ofte i et komplekst samspill. I denne artikkelen skal vi fokusere på noen av de viktigste resultatene fra senere års biologisk selumordsforskning.
\end{abstract}

R esultater fra mange såkalte psykologiske autopsi-studier har understreket hvilken stor betydning psykiske lidelser spiller i utvikling av selvmordsrisiko. Forskningen viser at det i mer enn $90 \%$ av alle selvmord kan påvises psykisk lidelse ( se bl.a. oversikt av I sometsä 2001). Samtidig vet vi at flertallet av alle dem som har en alvorlig psykisk lidelse, aldri gjør noe forsøk på å ta sitt eget liv. Psykisk lidelse kan al tså trolig anses som en noe nær nødvendig, men ikke tilstrekkelig betingelse for selvmord. Etter de psykologiske autopsistudiene har en nyere generasjon av studier basert på kasus-kontroll-design gitt mye verdifull informasjon om hvilke risikofaktorer som, i tillegg til psykisk lidelse, spiller inn ved selvmord. O gså grunnforskningen har fokusert på spørsmålet om hvorfor noen mennesker med psykisk lidel se ender opp i selvmord og andre ikke. $M$ an har etter hvert avdekket sammenheng med en rekke biologiske faktorer. I denne artikkelen skal vi ta et lite overblikk over kunnskapsstatus på dette feltet.

\section{Serotonin og selvmord}

På jakt etter det biologiske grunnlaget for depresjon ble man allerede på 1960tallet klar over at serotonin på ett eller annet vismåtte være knyttet til selvmordsrisiko. I hjernene til pasienter som var døde ved selvmord, fant man unormalt lave konsentrasjoner av 5-hydroxy-indoleddiksyre (5-H IA A ). 5-H IA A er det viktigste nedbrytningsproduktet i hjernens omsetning av serotonin (5-hydroxytryptamin) som er et viktig signalstoff i nervebaner som regulerer emosjoner som angst, tristhet og aggresjon. Selv om depresjon stod i fokus for disse studiene, fant man at bare om lag halvparten av de avdøde pasientene virkelig hadde hatt klinisk depresjon. I resten av tilfellene dreide det seg blant annet om schizofreni, personlighetsforstyrrelser og al koholisme. I 1970 påviste van Praag og medarbeidere at unormalt lav konsentrasjon av 5-HIA A ikke så ut til å være knyttet til noen spesifikk psykisk lidelse, men snarere til spesifikke psykiske dysfunksjoner slik som forstyrrelse i reguleringen av angst og aggresjon. Fra ca 1970 og utover viste en rekke studier at også blant levende pasienter som hadde gjort al vorlige sel vmordsforsøk, var det en klar tendens til unormalt lave konsentrasjoner av 5-HIA A, denne gangen målt i spinalvæsken (CSF). Sammenhengen mellom lave nivåer av CSF 5-H IA A og en forstyrret regulering av aggresjon er påvist både når det gjelder innadrettet og utadrettet aggresjon - både i grupper av suicidale personer ( $\AA$ sberg et al. 1976) og individer som har vist betydelig ten dens til voldelig atferd (Linnoila et al. 1983).

Studier har vist at forstyrrelsene i CSF 5-HIA A ikke er knyttet til sykdomsfase, men er vedvarende og kan påvises uavhengig av om den suicidale atferden inntraff nylig eller for flere år tilbake - altså at det dreier seg om et biologisk trekk eller hva vi kunne kalle en markør. Etter hvert som man har funnet holdepunkter for at denne markøren, Iav CSF 5-H IA A, medfører økt risiko for fremtidig suicidal atferd, har man også festet stadig større forhåpninger til at disse nye kunnskapene kan få klinisk nytteverdi. Blant annet har N ordström et al. (1994) vist at selvmordsforsøkere som hadde lave C SF 5H IA A verdier ved tidspunktet for innleggelse, hadde en økt risiko for gjentatte selvmordsforsøk året etter utskrivning. Det er interessant og klinisk betydningsfullt at C SF 5-HIA A konsentrasjonen ikke er korrelert med depresjonsgrad, men bare med selvmordsrisiko. Jo lavere C SF 5HIA A er, desto mer letal viser den suicidale atferden seg å være i undersøkte pasientgrupper ( $\mathrm{M}$ ann et al. 2001). Disse sammenhengene innebærer muligheter for at vi i fremtiden kan oppnå større effektivitet i vurderingen av selvmordsrisiko i forhold til dagens situasjon hvor vi sliter med balansen mellom sensitivitet og spesifisitet. I klinisk praksis handler dette om at vi strever for å identifisere flest mulig pasienter som er risikoutsatt for selvmord (sensitivitet) uten samtidig

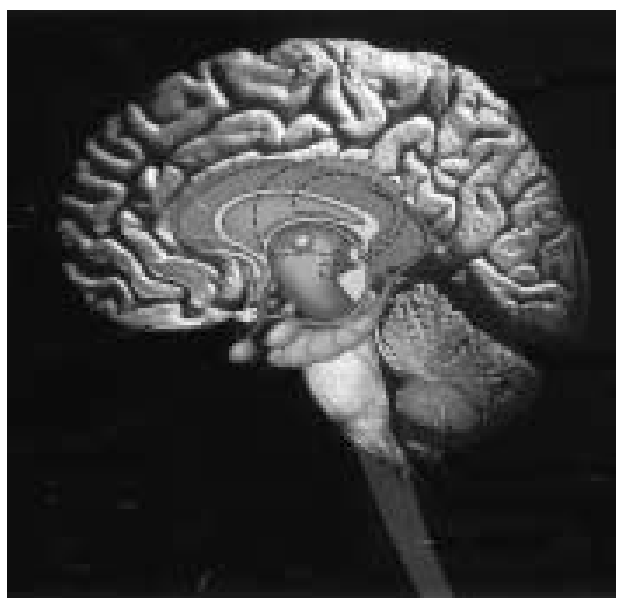

å favne altfor mange ikke-suicidale pasienter (spesifisitet). Pasienter som har det biologiske trekket som medfører vansker med regulering av affekter, burde ideelt sett tilbys forebyggen de behandling som hevet deres terskel for å reagere impul sivt suicidalt eller aggressivt.

M ålinger av C SF 5-HIA A konsentrasjoner krever spinal punksjon, og slike invasive metoder er det ikke nødvendigvis så enkelt å benytte i vanlig klinisk praksis. $M$ an har derfor vært på jakt etter alternative kilder til tilsvarende informasjon.

En slik kilde til informasjon om serotoninsystemet er målinger av prolaktin i blodbanen etter at man har gitt medikamenter som fenfluramin som utløser serotoninfrisetting i hjernen. Studier har vist at pasienter som tidligere har gjort selvmordsforsøk, har en redusert prolaktinrespons på fenfluramin (O'Keane et al. 1991).

I løpet av de senere år har forskningen knyttet til sammenhengen mellom serotonin og suicidalitet ekspandert, og vi vet nå at det ikke bare er nedbrytningen av serotonin som er forstyrret hos mange av de pasientene som strever med å kontrollere aggressive og suicidale impulser. O gså serotonin reseptorfunksjonen ser ut til å være forstyrret, særlig de såkalte 5 HT la og 5-H T 2c systemene. M en trolig gjelder det samme for disse forstyrrel sene som for forstyrrelsene i serotonin-metabolismen, at de er knyttet til endringer i psykologiske funksjoner, slik som regulering 
av angst og aggresjon, og ikke til spesifikke diagnoser. M an har også forsket på den anatomiske lokal isering av forstyrrel sene. Flere undersøkel ser tyder på at disse befinner seg i den ventrale prefrontale cortex.

\section{Kolesterol og suicidalitet}

Forskning har vist at et lavt kolesterolnivå (enten det er naturlig forekommende eller klinisk senket) henger sammen med økt tendens til selvmord og ulykkesdød (Kaplan et al. 1997). M ye tyder på at denne sammenhengen springer ut fra endringer i atferd og stemningsl eie som nettopp kan oppstå ved senkning i kolesterolnivået. Gjennom dyreforsøk har man studert endringer i kosthold og påfølgende endringer i atferd og hvilken sammenheng disse kan ha med endringer i biokjemiske prosesser i hjernen. Studiene viser at reduksjoner i kolesterolnivået øker impulsiv og aggressiv atferd hos forsøksdyrene gjennom å påvirke hjernens serotonerge systemer. En hypotese går ut på at når tilgangen på fettholdige næringsmidler kommer under et visst nivå, utløses mer jaktpreget og kompetitiv atferd hos forsøksdyrene - en mekanisme som sikrer større muligheter til overlevelse når det er knapphet på næring. H va slike studier innebærer for mennesker er fortsatt nokså uvisst, men to mulige lærdommer er: 1) lave verdier av kolesterol kan være en biologisk markør for selvmord og ulykkesdødsfall og 2) å senke kolesterolnivået medikamentelt eller gjennom diett kan muligens ha alvorlige bivirkninger for visse personer under visse omstendigheter (Kaplan et al. 1997).

\section{Stresshormoner og suicidalitet}

Et stort antall kliniske studier viser en klar sammenheng mellom belastende livshendelser og suicidal atferd. Det er også en erfaring at jo sterkere belastninger og jo flere områder av livet som er berørt av belastningene og jo lengre bel astningen(e) har virket, desto større er risikoen for utvikling av suicidal atferd. A ktivering av den såkalte hypothalamus hypofyse adreno-kortikale akse (H PA aksen) er kroppens sentrale endokrine respons på stress. 0 gså depresj onstilstander utl øses ofte av stressbelastning eller belastende livshendelser og ved depresjon ser vi ofte aktivering av H PA -aksen. Dette har vært obser- vert på flere måter, blant annet gjennom den såkalte dexamethason suppresjonstesten. I denne testen gis corticosteroidet dexamethason, og man måler deretter cortisol i blodet som under normale forhold skal synke, men ved positiv test ikke synker som tegn på at H PA -aksen er aktivert. 0 gså andre tester vil da kunne vise en aktivert H PA -akse, slik som TRH -test eller A C T H -test (Plotsky et al. 1998). D et ser ut til å være en sammenheng mellom det forhøyede cortisolspeilet i blodbanen under vedvarende stress og de tidligere nevnte forstyrrelsene i 5-H T-reseptorfunksjon. I laboratorieforsøk på rotter er det vist at kronisk uforutsigbart stress medfører høye serumcortisolnivåer og endringer i 5-H Treseptorfunksjonene. Dersom man på den annen side over tid gir forsøksdyret antidepressiva, forhindres flere av forstyrrelsene i 5 - H T reseptorfunksjonen og dessuten reverseres overaktiviteten i H PA aksen. Selv om dette foreløpig bare er laboratoriefunn, gir det oss visse holdepunkter for forståelsen av det biologiske substratet for sammenhengen mellom stressbelastning, sviktende affekt-kontroll og utvikling av suicidal atferd. N yere forskning på sammenhengen mellom omsorgssvikt og hjernens utvikling hos barn tyder også på at varige en dringer i H PA -aksens funksjon kan ha sitt opphav i kroniske stressbelastninger og svikt i de tidlige leveårene (G laser 2000).

\section{Genetiske faktorer}

Kliniske observasjoner har ofte vist at selvmord kan ha stor opphopning i visse familier. T villingstudier har bekreftet disse observasjonene og klart vist at det er en genetisk faktor ved selvmord. $N$ år den ene tvillingen har tatt sitt eget liv, er risikoen langt høyere for at også den andre vil gjøre selvmord (Roy et al. 1991) eller selvmordsforsøk (Roy et al. 1995). For toeggete tvillinger er risikoen mer en doblet sammenliknet med den generelle befolkning, og når det dreier seg om en eggete tvillinger (som jo har identisk arvemateriale) er risikoen ellevedoblet ( $M$ cG uffin et al. 2001). Disse funnene holder seg statistisk signifikante selv om man korrigerer for tilstedeværelsen av psykisk lidelse (W ender et al. 1986, Fu et al. 2002). Det er alstå ikke bare gjennom psykisk lidelse at den økte tilbøyelig heten til suicidal atferd arves, men også uavhengig av denne.

Den genetiske overføringen av selvmordsrisiko involverer høyst sannsynlig mange gener. Flere mulige gener er allerede

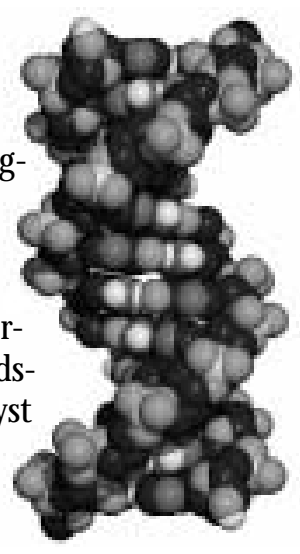
studert, særlig dem som er involvert i serotonin-omsetningen og den serotonerge transmisjon (Evans et al. 2000). $\mathrm{M}$ an har blant annet påvist såkalt polymorfisme i genet for enzymet tryptofan hydroksylase som har sterk påvirkning på produksjonsraten av serotonin ( $N$ ielsen et al. 1994).

For tiden pågår det en intens molekylærgenetisk forskning ( altså på det enkelte gen og de proteiner som dette genet koder for) på det suicidologiske fagfelt i likhet med de fleste andre områder i medisinen. Den funksjonelle genomforskningen (der man studerer mange geners funksjonelle samspill) vil trolig gi oss betydelig større innsikt i hvilke biokjemiske prosesser som er forstyrret ved en rekke former for suicidalitet og hvordan selvmordsrisiko kan overføres biologisk. Dette vil være et meget verdifullt supplement til vår allerede omfattende kunnskap om den sentrale betydningen av miljømessige faktorer både tidlig og senere i livet.

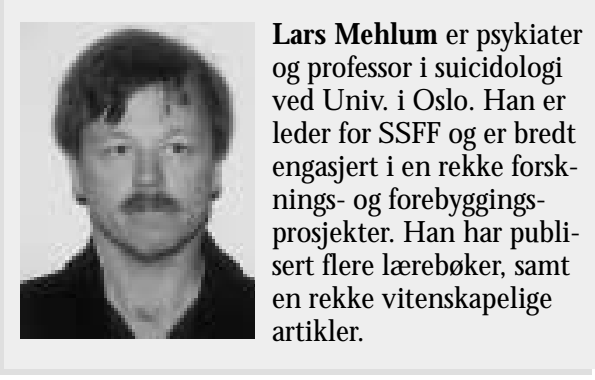

\section{Litteratur}

Evans J, Reeves B, Platt H, Leibenau A, G oldman $D$, Jefferson $K, N$ utt $D$. Impulsiveness, serotonin genes and repetition of deliberate self-harm (DSH). Psychol M ed 2000; 30: 1327-34.

Fu Q, H eath A C, BucholzKK, N elson EC, G lowinski A L, G oldberg J, Lyons M J, Tsuang M T, Jacob T, True MR, Eisen SA. A twin study of genetic and environmental influences on suicidality in men. Psychol M ed 2002; 32: 11-24.

(Forts. S. 17) 


\section{Tverrfaglighet er ønskelig}

For egen del vil jeg si at i utarbeidelsen av kurskonseptet ligger det som en viktig, men ikke absolutt nødvendig premiss at kurset skal være tverrfaglig sammensatt. 0 ptimale læringsbetingelser oppnås når deltakerne representerer ulike befolkningsgrupper og kulturer. Fra en kursleder med noe erfaring er det fristen de å legge til at det i møtet mellom forskjellige yrkeskulturer ofte oppstår spennende utfordringer som også bidrar til å bryte ned barrierene og revirtenkningen gruppene i mellom. Som et eks. på dette kan jeg vise til at politifolk ofte fremstår som svært handlingsorienterte i møtet med selvmordstruede mennesker. For mange kursdeltakere er dette en positiv overraskelse og bidrar til å øke læringsutbyttet for alle. Førstehjelp ved selvmordsfare dreier seg nettopp om å intervenere raskt slik at liv ikke går tapt. Det er for øvrig et prinsipp som gjelder all førstehjelp. Selvmordsatferd representerer ingen unntak fra denne regelen.

(Dag W illy Tallaksen er undervisningskonsulent ved SSF F.)

Forts. fra s. 12 (- M ehlum)

G laser D. C hild abuse and neglect and the brain - a review. J Child Psychol Psychiatry 2000; 41(8): 1076.

Isometsä ET. Psychological autopsy studies - a review. Eur Psychiatry 2001;16 (7): 379-85.

Kaplan JR, M uldoon M F, M anuck SB, M ann JJ. A ssessing the observed relationship between low cholesterol and violence-related mortality. I mplications for suicide risk. A nn N Y A cad Sci 1997; 29 (836): 57-80.

Linnoila $M$, Virkkunen $M$, Scheinin $M, N$ uutila $A$, Rimon R, Goodwin FK. Low cerebrospinal fluid 5-hydroxyindoleacetic acid concentrations differentiates impulsive from non-impulsive violent behavior. Life Sciences 1983; 33(26): 2609-14.

LopezJF, Vazquez DM , Chalmers DT, W atson SJ. R egulation of 5-H T receptors and the hypothalamic-pituitary-adrenal axis. Implications for the neurobiology of suicide. A nn N Y A cad Sci 1997; 29(836): 106-34.

M ann JJ, A rango $V$. N eurobiology of suicidal behavior. I: W asserman D (ed). Suicide - an unnecessary death. London: Dunitz, 2001.

$M$ CG uffin $P$, M arusic A, Farmer $A$. What can psychiatric genetics offer suicidology? C risis 2001; 22(2): 61-5.

$N$ ielsen $D, G$ oldman $D$, Virkkunen M, Tokola R Rawlings R, Linnoila M. Suicidality and 5-hydro- xyindoleacetic acid concentration associated with a tryptophane hydroxylase polymorphism. A rch G en Psychiatry 1994; 51: 34-8.

N ordström P, Samuelsson M, A sberg M , TräskmanBendz L, A berg-W istedt A, N ordin C, Bertilsson L. C SF 5-H IA A predicts suicide risk after attempted suicide. Suicide \& Life-threatening Behav 1994; 24: 1-9.

0 'Keane V, Dinan T G. Prolactin and cortisol responses to $D$-fenfluramin in major depression evidence for diminshed responsivity of central serotonergic function. A m J Psychiatry 1991; 148 1009-15.

Plotsky PM, O wens M J, N emeroff C B. Psychoneuroendocrinology of depression. $H$ ypothalamicpituitary-adrenal axis. Psychiatr C lin N orth A m 1998; 21(2): 293-307.

Roy A, Segal N, C enterwall D, Robinette D.

Suicide in twins. A rch G en Psychiatry 1991; 48: 29-32.

Roy A, Segal N, Sarchiapone M. A ttempted suicide among living cotwins of twin suicide victims. A m J Psychiat 1995; 152: 1075-6.

Van Praag H M, Korf J, Puite J. 5-hydroxyindoleacetic acid levels in the cerebrospinal fluid of depressive patients treated with probenecid. N ature 1970; 225: 1259-60.

W ender $P$, K ety $S$, R osenthal D, Schulsinger $F$, Ortmann J, Lunde I. Psychiatric disorders in the biological and adoptive families of adopted individuals with affective disorders. A rch $G$ en Psychiatry 1986; 43: 923-9.

A sberg M, Träskman L, Thorén P. 5-HIA A in the cerebrospinal fluid: A biochemical suicide predictor. A rch G en Psychiatry 1976; 33: 1193-7.

Forts. fra S. 10 (- M iller og H artstein)

Shaffer D, G ould M \& HicksR. W orsening suicide rate in black teenagers. A merican Journal of Psychiatry 1994; 151: 1810-1812.

Shaffer $D \& H$ icks R. T he epidemiology of child and adolescent suicide. In B.Pless (Ed.), The Epidemiology of $C$ hildhood Disorders. N ew York: Oxford U niversity Press, 1993.

Spirito A, Brown L, O verholser J \& Fritz G . $A$ ttempted suicide in adolescence: $A$ review and critique of the literature. C linical Psychology Review 1989; 9: 335-363.

Sunseri PA. Preliminary outcomes on the use of D ialectical Behavior T herapy to reduce hospitalization among adolescents in residential care. In press. 1-26. (2002)

Tondo L \& Baldessarini RJ. Suicide: A n overview. Psychiatry Clinical M anagement 2001; 3: 1-36.

Trautman $\mathrm{P}$, Stewart $\mathrm{N} \& \mathrm{M}$ orishima $\mathrm{A}$. A re adolescent suicide attempters non-compliant with outpatient care? J ournal of the A merican A cademy of $C$ hild and A dolescent Psychiatry 1993; 32: 89-94

Wood A, Trainor G, Rothwell J, M oore A \& $H$ arrington $R$. R andomized trial of group therapy for repeated deliberate self-harm in adolescents. Journal of the A merican A cademy of $C$ hild and A dolescent Psychiatry 2001; 40: 1246-1253.
Forts. fra s. 15 (- G jertsen)

Simpura J, Levin BM . D emystifying R ussian drinking. A $\mathbf{n}$ introduction. In: Simpura $\&$ Levin BM (eds). Demystifying Russian D rinking. Comparative Studies from the 1990s. STA KES, Research Report 85. H elsinki, 1997.

Thelle DS. D ødelighetsutviklingen i R ussland. Tidsskr N or Lægeforen 1999; 119: 1482-4.

U.S. C ensus Bureau, International Programs $C$ enter. $C$ ensus dates for countries and areas of the world: 1945 to 2004. Last revised $15 \mathrm{~A} \mathrm{ug}$ 2001. http://www.census.gov/ipc/www/cendates/

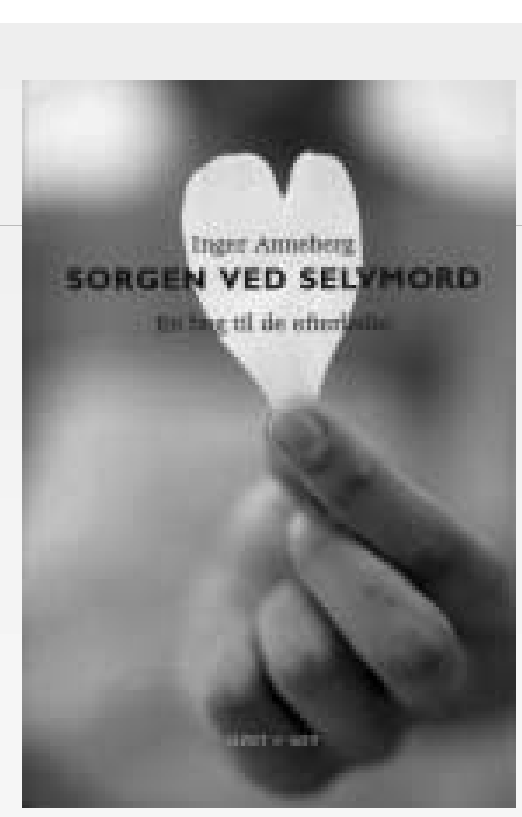

A nneberg, Inger

Sorgen ved selvmord: en bog til de efterladte.

København: Høst \& Søn, 2002.

$-373 \mathrm{~s}$.

ISBN 87-14-29766-3

"D enne bog er skrevet med ét formål: A t give mæle til mennesker, der ofte bliver mødt med tavshed." Slik åpner A nneberg sin bok der hun har intervjuet mange mennesker som har opplevd at en som stod dem nær, døde ved selvmord. Barn og voksne forteller om sine erfaringer og overlevelsesstrategier. Fagfolk er også intervjuet. 